OPEN ACCESS

Citation: S. Weine Paulino Chaves, R. Duarte Coelho, J. de Oliveira Costa, S. André Tapparo (2021) Micrometeorological modeling and water consumption of tabasco pepper cultivated under greenhouse conditions. Italian Journal of Agrometeorology (1): 21-36. doi: $10.36253 /$ ijam-1221

Received: February 14, 2021

Accepted: May 26, 2021

Published: August 9, 2021

Copyright: (c) 2021 S. Weine Paulino Chaves, R. Duarte Coelho, J. de Oliveira Costa, S. André Tapparo. This is an open access, peer-reviewed article published by Firenze University Press (http://www.fupress.com/ijam) and distributed under the terms of the Creative Commons Attribution License, which permits unrestricted use, distribution, and reproduction in any medium, provided the original author and source are credited.

Data Availability Statement: All relevant data are within the paper and its Supporting Information files.

Competing Interests: The Author(s) declare(s) no conflict of interest.

\section{Micrometeorological modeling and water consumption of tabasco pepper cultivated under greenhouse conditions}

\author{
Sérgio Weine Paulino Chaves ${ }^{1}$, Rubens Duarte Coelho ${ }^{2}$, Jéfferson de \\ Oliveira Costa ${ }^{2, *}$, Sergio André TApparo ${ }^{3}$ \\ ${ }^{1}$ Federal Rural University of the Semi-Arid/UFERSA, Department of Environmental and \\ Technological Sciences, Francisco Mota, 572, 59625-900, Mossoró, RN, Brazil \\ ${ }^{2}$ University of São Paulo/USP-ESALQ, Department of Biosystems Engineering, C.P. 09, \\ 13418-900 Piracicaba, SP, Brazil \\ ${ }^{3}$ Federal Institute of Mato Grosso do Sul/IFMS, Campus Ponta Porã, highway BR-463, \\ km 14, 79909-000, Ponta Porã, MS, Brazil \\ ${ }^{\star}$ Corresponding author. E-mail address: costajo@alumni.usp.br
}

\begin{abstract}
Micrometeorological variables of tabasco pepper cultivated under greenhouse and drip irrigated conditions have not been presented to date in literature, especially the water consumption of these plants, in terms of crop evapotranspiration $\left(\mathrm{ET}_{\mathrm{c}}\right)$ and crop coefficient $\left(\mathrm{K}_{\mathrm{c}}\right)$. The determination of these variables is extremely important for the application of the correct amount of water to irrigated crops in these environments because PM FAO (56) standard methodology was idealized for outdoor environments. The objective of this work was to develop models of estimation of micrometeorological variables in greenhouse conditions and to determine the water demand, in terms of evapotranspiration (ET) and $\mathrm{K}_{\mathrm{c}}$, of the pepper (Capsicum frutescens L.), cv. Tabasco McIlhenny, drip irrigated using drainage lysimeters. The research was carried out in an experimental area located at the University of Sao Paulo (USP) in Piracicaba, SP, Brazil. The following micrometeorological variables were monitored: air temperature, air relative humidity (digital thermohygrometer) and evaporation (mini-pan) (EMT). Drainage lysimeters were used to obtain the $\mathrm{ET}_{\mathrm{c}}$ and the reference evapotranspiration $\left(\mathrm{ET}_{\mathrm{o}}\right)$ was estimated outside the greenhouse by the Penman Monteith (ET $\mathrm{PM})$, Hargreaves and Samani (ET $\mathrm{E}_{0} \mathrm{HS}$ ) methods and the class "A" pan method (ECA). It was concluded that the total value of mini-pan evaporation (EMT) inside the greenhouse was practically equal to $\mathrm{ET}_{\mathrm{o}} \mathrm{PM}, 5 \%$ lower than $\mathrm{ET}_{\mathrm{o}} \mathrm{HS}$ and $31 \%$ higher than $\mathrm{ECA}$ in the outdoor environment. ET values ranged from 0.28 to $2.42 \mathrm{~mm} \mathrm{day}^{-1}$ and total crop ET was 446.43 $\mathrm{mm}$. The $\mathrm{K}_{\mathrm{c}}$ values for the first pepper production cycle were: 0.17 in the initial phase, 0.76 in the flowering and fruiting phase and 0.39 in the harvest phase, for the second production cycle, the value of $\mathrm{K}_{\mathrm{c}}$ was 0.50 at the harvest phase.
\end{abstract}

Keywords: Capsicum frutescens L, evapotranspiration, lysimetry, micro irrigation.

\section{INTRODUCTION}

Changes in micrometeorological variables as air temperature, relative humidity, radiation and evapotranspiration for crops under plastic-covered 
environments have been studied in several locations in Brazil (Andrade Júnior et al., 2011; Costa et al., 2015; Chavaria et al., 2009) and the world (Kittas and Bartzanas, 2007; Meiri et al., 2011; AbdelGhany and Helal, 2011; Giménez et al., 2013; Qiu et al., 2015), either for research as well as commercial purposes, where the methodology FAO (56) $\mathrm{ET}_{0} \mathrm{PM}$ standard that is recommended for outdoor use requires some adaptations to be used under greenhouse conditions.

Allen et al. (1998) suggested that for the reference evapotranspiration calculation $\left(\mathrm{ET}_{\mathrm{o}}\right)$ under greenhouse conditions, the wind speed at two meters height should be set at $0.5 \mathrm{~m} \mathrm{~s}^{-1}$, because according to the same authors, this improves the accuracy of estimates in very low wind speed conditions, however, do not present any experiments that support this practical suggestion.

Studies show that the ratio between crop evapotranspiration $\left(\mathrm{ET}_{\mathrm{c}}\right)$ in greenhouse and $\mathrm{ET}_{\mathrm{o}}$ in outdoor environment can also cause a variation in the estimate of crop coefficient $\left(\mathrm{K}_{\mathrm{c}}\right)$. In the greenhouse, in general, the $\mathrm{ET}_{\mathrm{o}}$ is lower, around 60 to $80 \%$ of that found in outdoor environments (Farias et al., 1994; Orgaz et al., 2005; Qiu et al., 2011).

In the specific case of Capsicum species, which have a growing cycle of 120 to 150 days and consume between 600 and $1250 \mathrm{~mm}$ of water, depending on climatic conditions and the variety planted, the average $\mathrm{K}_{\mathrm{c}}$ is 0.40 immediately after transplantation, 0.95 to 1.10 during the period of full coverage and, for green peppers, 0.80 to 0.90 at harvest (Doorenbos and Kassam, 2000).

Chaves et al. (2005) and Miranda et al. (2006) studied the water demand of the tabasco pepper (Capsicum frutescens L.) under field conditions in the semi-arid climate region (Northeast Brazil) and observed a total evapotranspiration of $1083 \mathrm{~mm}$ of water for one cycle of 135 days, based on sprinkler irrigation and using three drainage lysimeters to determine water consumption. The average water consumption during crop cycle was $7.4 \mathrm{~mm} \mathrm{day}^{-1}$.

Meanwhile, Miranda et al. (2006) under similar conditions, observed that pepper plants consumed an average of $888 \mathrm{~mm}$ for a 300-day cycle with drip irrigation system and using a weighing lysimeter to determine water consumption. They obtained $\mathrm{ET}_{\mathrm{c}}$ values for tabasco pepper, which ranged from 1.0 to $5.6 \mathrm{~mm} \mathrm{day}^{-1}$. However, studies on the water consumption of pepper crop under greenhouse conditions are still unavailable in literature.

Commercial tabasco pepper planted at outdoor conditions, usually suffer from bird attack who really appreciate the fruit flavor, in this way, they must be kept at a certain distance from the plantation to avoid damages; the must friendly way of doing this is the pepper cultivation under greenhouse conditions. Traditionally, family farmers are the main producers of tabasco pepper, thus the use of low-cost equipment to control irrigation as the class A mini-pan must be emphasized in research and extension purposes.

This work is based on the hypothesis that micrometeorological variables under greenhouse conditions can be estimated by regression equations created from data collected at a suitably open weather station near these greenhouses. In addition, the use of drainage lysimeters to determine the $\mathrm{ET}_{\mathrm{c}}$ of pepper under greenhouse may be a precise way of obtaining $\mathrm{K}_{\mathrm{c}}$ and assist in determining the correct amount of water for pepper irrigation in these environments.

In this context, the objective of this work was to develop equations for estimation of micrometeorological elements under greenhouse conditions and to determine the water demand, in terms of evapotranspiration and $\mathrm{K}_{\mathrm{c}}$, of the pepper (Capsicum frutescens L.) cv. Tabasco McIlhenny, drip irrigated and cultivated under greenhouse using drainage lysimeters.

\section{MATERIAL AND METHODS}

\subsection{Location and characterization of the experimental area}

The work was conducted in an experimental area of the Biosystems Engineering Department (ESALQ), University of São Paulo (USP), located in Piracicaba, State of São Paulo (2242’30" S, 47³8'00" W; elevation of $546 \mathrm{~m}$ ), southeastern Brazil. The local climate, according to the Köppen classification, is Cwa type (Alvares et al., 2013), dry winter and warmer month temperature greater than $22^{\circ} \mathrm{C}$, average temperature $21.6^{\circ} \mathrm{C}$, average relative humidity of $73 \%$ and annual precipitation of $1280 \mathrm{~mm}$.

The experiment was carried out in a greenhouse composed of two twinned spans (with galvanized metal structure), arc cover (with high density transparent polyethylene diffuser film, 150 microns). The greenhouse had the following dimensions: $14 \mathrm{~m}$ wide, $22 \mathrm{~m}$ long, central height $4.0 \mathrm{~m}$ and ceiling height $2.5 \mathrm{~m}$ (consisting of four front windows at the ends). The closed sides with protective screen (50\% shade) and $20 \mathrm{~cm}$ reinforced concrete skirting board (Fig. 1A). Inside the greenhouse, 112 vases of $500 \mathrm{~L}$ were distributed in rows. The fiber cement vases had the following dimensions: $0.92 \mathrm{~m}$ wide, $1.08 \mathrm{~m}$ long and $0.65 \mathrm{~m}$ high (Fig. 1B). At the bottom of the vase was placed a $5 \mathrm{~cm}$ thick layer of gravel, covered by a geotextile blanket. A $25 \mathrm{~mm}$ diameter PVC drain was also installed, drilled and covered at the bottom by the geotextile blanket and buried vertically in the ground. The geographic coordinates of the greenhouse are: $22^{\circ} 42^{\prime} 39^{\prime \prime}$ S lat., $47^{\circ} 37^{\prime} 45^{\prime \prime} \mathrm{W}$ long. and elevation of $546 \mathrm{~m}$. 


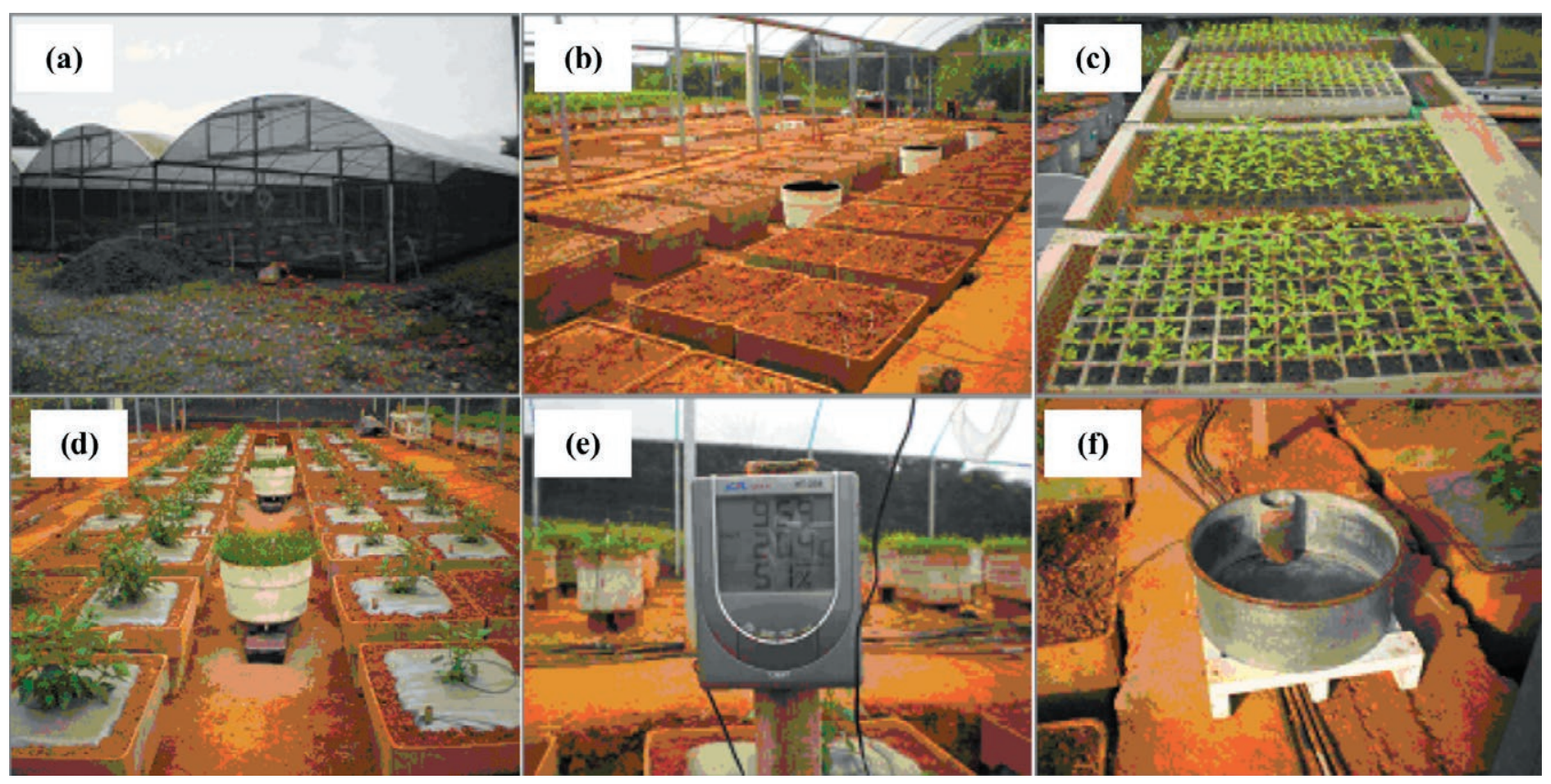

Fig. 1. Images of the experimental area and equipment used for monitoring meteorological variables. External view of the greenhouse used in the experiment (A); Internal view of the greenhouse with the distribution of the vases used for planting the crop (B); Trays used for sowing (C); Internal view of the greenhouse after planting the seedlings and view of the drainage lysimeters in the center (D); Digital thermohygrometer used (E); Mini-pan used in the experiment (F).

Making a general comparison with the average external field conditions and agricultural practices adopted in Brazil, we can say that in general the cultivation is done in home gardens for domestic consumption and in commercial gardens that supply the local markets. The spacing used is 1.2 to $1.5 \mathrm{~m}$ between rows, by $0.6 \mathrm{~m}$ between plants, in general. Productivity is around $15 \mathrm{Mg} \mathrm{ha}^{-1}$ (Chaves et al., 2005). They are grown in regions with variable rainfall from 600 to $1200 \mathrm{~mm}$ and an average temperature of $25^{\circ} \mathrm{C}$.

\subsection{Planting and conduction the crop}

The genetic material used was pepper (Capsicum frutescens $\mathrm{L}$.) cv. tabasco. Sowing was performed in 128 cell trays (Fig. 1C) and at 57 days after sowing (DAS) the seedlings were transplanted to the greenhouse. The spatial arrangement used for greenhouse planting was in double rows, with a spacing of $2.58 \times 0.92 \mathrm{~m}$ (between rows) and $1.57 \mathrm{~m}$ (between plants), with one seedling per vase (Fig. 1D), resulting in a population of 3636 plants ha $\mathrm{a}^{-1}$. The vases received a mulching and the plants were conducted with two pruning plants, resulting in sixteen branches: the first at 7 days after transplanting (DAT), leaving the plant with two pairs of leaves; and the second at $62 \mathrm{DAT}$, leaving the plant with four branches and two pairs of leaves per branch. The peppers were harvested from 185 to $350 \mathrm{DAT}$, when they reached the characteristic color of the cultivar.

Planting fertilization was performed based on the chemical analysis of the soil, according to Raij et al. (1996), applying the following products: monoammonium phosphate, simple superphosphate, potassium chloride, zinc sulfate and boric acid. In conducting the crop, fertigation was performed based on nutrient concentrations recommended for hydroponic cultivation of peppers. Fertilizers applied via fertigation were ammonium nitrate, calcium nitrate, monoammonium phosphate, monopotassium phosphate, potassium chloride (white), potassium sulfate, potassium nitrate and magnesium sulfate.

Phytosanitary treatments were performed periodically throughout the crop cycle, starting at 15 DAT, at intervals of 15 to 20 days, respecting the deficiencies of the products. Manual weeding was carried out, so that the plants were always free from competitors. The irrigation system was based on one dripper per plant. Each dripper was connected to a 4 microtube discharge divider with dripper piles, evenly positioned in each vase. Irrigation depths were applied as a function of total irrigation need (NTI) and soil cover. The NTI was calculated daily from the $\mathrm{ET}_{\mathrm{c}}$ estimate using drainage lysimeters installed inside the greenhouse (Fig. 1D). 
For the analysis of the performance of the irrigation system, data were collected by means of flow uniformity tests in all drippers. The parameters used to evaluate the uniformity of the irrigation system used were the Christiansen Uniformity Coefficient - CUC, the Emission Uniformity - EU, also known as the Distribution Uniformity Coefficient - CUD and the Application Efficiency - Ea. On average, a water application efficiency of $91 \%$ was obtained based on the evaluation of the irrigation system.

\subsection{Monitoring of weather variables}

The meteorological variables monitored during the experiment were: air temperature, relative humidity and evaporation. To obtain temperature and humidity values, a digital thermohygrometer was installed inside the greenhouse at $2 \mathrm{~m}$ height (Fig. 1E). The equipment stored in the memory the daily maximum and minimum measurements, after the readings, between 8 and 9 am, the daily averages of temperature and humidity were calculated. Evaporation values of the mini-pan were obtained daily, between 8 and 9 am, by means of a micrometer screw, accurate to $0.02 \mathrm{~mm}$, and a minipan that had $0.60 \mathrm{~m}$ in diameter and $0.25 \mathrm{~m}$ high and was installed $5 \mathrm{~m}$ from the end of the greenhouse on a wooden platform to prevent the pan from contacting the ground and to allow air circulation (Fig. 1F).

The values of the maximum, average and minimum temperatures, and the humidity obtained in the ESALQ/USP automatic weather station were correlated by simple linear regression (RLS) for the autumn, winter, spring and summer seasons, with their values elements obtained inside the greenhouse. In this case, the temperature data were collected by sensors installed at $2 \mathrm{~m}$ height and protected against direct solar radiation. The collection height is the same as the sensors installed inside the greenhouse because the vases that received the plants were positioned in an excavated way in the soil, so that the edge of the vase coincided with the soil surface.

Evaporation values of the mini-pan inside the greenhouse were correlated, also by RLS, for the intervals of 1, 3, 5 and 7 days, with the $\mathrm{ET}_{\mathrm{o}}$ values in the outdoor environment. Thus, we analyzed the possibility of using external data to estimate data inside the greenhouse.

\subsection{Determination of crop water requirement}

The $\mathrm{ET}_{\mathrm{c}}$ was obtained for each phase of crop development, corresponding to the difference between the volume of water placed on the lysimeter and the drained volume (liters), divided by the area $\left(\mathrm{m}^{2}\right)$ equivalent to the crop spacing.

The $\mathrm{ET}_{\mathrm{c}}$ estimate began at 20 DAT, when it was verified that the water storage in the lysimeters were in equilibrium. For the estimation of $\mathrm{ET}_{\mathrm{o}}$ outside the greenhouse, the methods of Penman Monteith (ET $\mathrm{PM}$ ), Hargreaves and Samani (ET $\mathrm{ET}_{\mathrm{O}} \mathrm{H}$ ) and the class "A" pan (ECA), were used, according to Equations 1, 2 and 3, respectively. The calculations were performed based on the weather data of the ESALQ/USP automatic station, collected from June 2007 to April 2008, thus 330 days in total. The ESALQ/USP meteorological station is located on the premises of Biosystems Engineering Department (LEB). The geographical coordinates of the post are as follows: 2242’30” S lat., 47³8’00” W long. and elevation of 546 meters. The post consists of a conventional station and an automatic station, which performs meteorological observations every 15 minutes. The automatic station started in 1997 and regularly records data on precipitation, temperature, air humidity, solar radiation, radiation balance, evapotranspiration, speed and wind direction.

$\mathrm{ET}_{0} \mathrm{PM}=\frac{0,408 \mathrm{~s}\left(\mathrm{R}_{\mathrm{n}}-\mathrm{G}\right)+\frac{\gamma 900 \mathrm{U}_{2}\left(\mathrm{e}_{\mathrm{s}}-\mathrm{e}_{\mathrm{a}}\right)}{\mathrm{T}+273}}{\mathrm{~s}+\gamma\left(1+0,34 \mathrm{U}_{2}\right)}$

where $\mathrm{ET}_{\mathrm{o}} \mathrm{PM}$ is the reference evapotranspiration, Penman-Monteith (PM) (mm day $\left.{ }^{-1}\right), \mathrm{Rn}$ is the total daily net radiation $\left(\mathrm{MJ} \mathrm{m} \mathrm{m}^{-2} \mathrm{day}^{-1}\right), \mathrm{G}$ is the soil heat flux $\left(\mathrm{MJ} \mathrm{m} \mathrm{m}^{-2}\right.$ day $\left.^{-1}\right), \gamma$ is the psychrometric constant $\left(\mathrm{kPa}{ }^{\circ} \mathrm{C}^{-1}\right)$, $\mathrm{T}$ is the mean air temperature $\left({ }^{\circ} \mathrm{C}\right), \mathrm{U}_{2}$ is the wind speed at 2 $\mathrm{m}$ high $\left(\mathrm{m} \mathrm{s}^{-1}\right)$, es is the vapor saturation pressure $(\mathrm{kPa})$, ea is the vapor partial pressure $(\mathrm{kPa})$ and $\mathrm{s}$ is the slope of the vapor pressure curve at air temperature $\left(\mathrm{kPa}^{\circ} \mathrm{C}^{-1}\right)$.

$\mathrm{ET}_{\mathrm{o}} \mathrm{HS}=0.0023$ Qo $(\mathrm{Tmax}-\mathrm{Tmin})^{0.5}(\mathrm{~T}+17.8)$

where $\mathrm{ET}_{\mathrm{o}} \mathrm{HS}$ is the reference evapotranspiration, Hargreaves-Samani (HS) (mm day $\left.{ }^{-1}\right)$, Qo is the extraterrestrial global solar radiation $\left(\mathrm{mm}\right.$ day $\left.^{-1}\right), \mathrm{T}_{\mathrm{MAX}}$ is the maximum air temperature $\left({ }^{\circ} \mathrm{C}\right), \mathrm{T}_{\mathrm{MIN}}$ is the minimum air temperature $\left({ }^{\circ} \mathrm{C}\right)$ and $\mathrm{T}$ is the average air temperature $\left({ }^{\circ} \mathrm{C}\right)$.

$\mathrm{ET}_{\mathrm{o}} \mathrm{ECA}=\mathrm{Kp} \mathrm{ECA}$

where $\mathrm{ET}_{\mathrm{o}} \mathrm{ECA}$ is the reference evapotranspiration, class " $A$ " pan (ECA) (mm day $\left.{ }^{-1}\right), \mathrm{Kp}$ is the coefficient class " $A$ " pan (dimensionless), according to Equation 4, and ECA is the evaporation class " $\mathrm{A}$ " pan $\left(\mathrm{mm} \mathrm{day}^{-1}\right)$.

$\mathrm{Kp}=0.482+0.024 \mathrm{Ln}(\mathrm{B})-0.000376 \mathrm{U}+0.0045 \mathrm{RH}$

where B is the surround $(\mathrm{m}), \mathrm{U}$ is the wind speed $(\mathrm{km}$ day $^{-1}$ ) and RH is the average daily relative humidity (\%). 
Table 1. Development stages of the pepper crop adapted for the experiment in question.

\begin{tabular}{lccccccc}
\hline Phases & Phase I & Phase II & Phase III & Phase IV & Phase V & Phase VI & Phase VII \\
\hline $\begin{array}{l}\text { Periods (days) } \\
\text { Years }\end{array}$ & $0-96$ & $97-166$ & $167-186$ & $187-225$ & $226-245$ & $246-267$ & $268-350$ \\
Months & May to August & $\begin{array}{c}\text { September to } \\
\text { November }\end{array}$ & November & $\begin{array}{c}\text { December to } \\
\text { January }\end{array}$ & January & February & February to April \\
\hline
\end{tabular}

With the results obtained from $\mathrm{ET}_{\mathrm{c}}$ and $\mathrm{ET}_{\mathrm{o}}$, the $\mathrm{K}_{\mathrm{c}}$ was calculated according to Equation 5 for the different stages of development throughout phenological cycle, by the ratio between $\mathrm{ET}_{\mathrm{c}}$ and $\mathrm{ET}_{\mathrm{o}}$.

$\mathrm{Kc}=\frac{\mathrm{ETc}}{\mathrm{ETO}}$

In the $\mathrm{ET}_{\mathrm{c}}$ and $\mathrm{K}_{\mathrm{c}}$ analyzes, the different developmental stages were adapted, according to Allen et al. (1998), and divided into seven phases: Phase I: Initial, from the time of transplantation to the point where the crop reaches approximately $20 \%$ of its development; Phase II: development-flowering, beginning at the end of phase I and ending at a point immediately before flowering-fruiting, which corresponds to a range of 70 to $80 \%$ of vegetation cover; Phase III: flowering-fruiting period; Phase IV: flowering-fruiting-harvest period from the end of phase III to the harvest. Phase V: end of first production cycle, harvest period; Phase VI: flowering-fruiting period, begins at the end of phase $\mathrm{V}$ and ends at a point immediately before flowering-fruiting-harvesting of the second production cycle; Phase VII: flowering-fruitingharvest period (Table 1).

\section{RESULTS AND DISCUSSION}

\subsection{Air temperature variation and correlation}

Fig. 2A, 2B and 2C illustrate, respectively, the variations in maximum $\left(\mathrm{T}_{\mathrm{MAX}}\right)$, average $\left(\mathrm{T}_{\mathrm{MED}}\right)$ and minimum $\left(\mathrm{T}_{\mathrm{MIN}}\right)$ temperatures (observed and estimated) inside the greenhouse and outside during the pepper cycle, comprised between 23 DAT, initial phase, and 350 DAT, last harvest, within 327 days.

The average values of $\mathrm{T}_{\mathrm{MAX}}$ observed inside the greenhouse and outdoors for the autumn, winter, spring and summer seasons were 40 and $27^{\circ} \mathrm{C}, 36$ and $28^{\circ} \mathrm{C}$, 42 and $30^{\circ} \mathrm{C}$ and 44 and $30^{\circ} \mathrm{C}$, respectively, representing a significant percentage difference of approximately 33 , 22,29 and $32 \%$. For $\mathrm{T}_{\mathrm{MED}}$, the mean values were, respectively, 28 and $20^{\circ} \mathrm{C}, 25$ and $20^{\circ} \mathrm{C}, 30$ and $23^{\circ} \mathrm{C}$ and 32 and $23^{\circ} \mathrm{C}$, with a difference of approximately $29,20,23$ and $28 \%$. Finally, $\mathrm{T}_{\mathrm{MIN}}$, which presented the respective average values of 16 and $15^{\circ} \mathrm{C}, 13$ and $12{ }^{\circ} \mathrm{C}, 18$ and $17^{\circ} \mathrm{C}$ and 20 and $19^{\circ} \mathrm{C}$, representing a difference of approximately $1^{\circ} \mathrm{C}$ in both stations.

Vásquez et al. (2005), working in a greenhouse, in the same place, in the spring-summer season from 2001 to 2002, found average values of $\mathrm{T}_{\mathrm{MAX}}, \mathrm{T}_{\mathrm{MED}}$ and $\mathrm{T}_{\mathrm{MIN}}$ of 34,25 and $18^{\circ} \mathrm{C}$, respectively. Frizzone et al. (2005), also in the same place, in the summer of 2001, found average values of 35,24 and $13^{\circ} \mathrm{C}$, respectively, for $\mathrm{T}_{\mathrm{MAX}}, \mathrm{T}_{\mathrm{MED}}$ and $\mathrm{T}_{\mathrm{MIN}}$.

From the beginning to the end of the cultivation cycle, in general, the average values of $\mathrm{T}_{\mathrm{MAX}}, \mathrm{T}_{\mathrm{MED}}$ and $\mathrm{T}_{\text {MIN }}$ observed inside the greenhouse and outside were 41 and $29^{\circ} \mathrm{C}, 29$ and $22^{\circ} \mathrm{C}$ and 17 and $16^{\circ} \mathrm{C}$, respectively, representing a difference of 29,24 and $6 \%$. The ideal averages of $\mathrm{T}_{\mathrm{MAX}}$ and $\mathrm{T}_{\mathrm{MIN}}$ are, respectively, 35 and $18^{\circ} \mathrm{C}$, and the optimal range of $\mathrm{T}_{\mathrm{MED}}$ for the pepper development cycle is between 21 and $30^{\circ} \mathrm{C}$ (Mercado et al., 1997). Low temperatures slow the development of the plant, while high temperatures associated with low relative humidity lead to the autumn of flowers and fruits.

It was found that in $86 \%$ of the evaluated days, $\mathrm{T}_{\mathrm{MAX}}$ exceeded the value of $35^{\circ} \mathrm{C}$ (Fig. $2 \mathrm{~A}$ ) and in $50 \%$ of those days it was below $18^{\circ} \mathrm{C}$ (Fig. 2C), these being the critical stages of flowering and fruiting and plant development. In only $4 \%$ of days, $\mathrm{T}_{\mathrm{MED}}$ in the greenhouse was below $21^{\circ} \mathrm{C}$, in $26 \%$ of the days evaluated it was above $30^{\circ} \mathrm{C}$ and in $70 \%$ it was within the optimal range (Fig. $2 \mathrm{~B}$ ), considered for the cycle crop development. A response to no stress condition came in the average pepper yield values obtained in the experiment, as shown in Table 2 .

Therefore, given the temperature values and the behavior of the pepper throughout the cycle, it was observed that the optimal temperature range, between 21 and $30^{\circ} \mathrm{C}$, predominated during the experimental phase. The average temperature seems to be the most important variable for the good development of the crop in greenhouse. Research carried out in the same experimental greenhouse and monitoring the environment temperature has achieved good results regarding the development of other crops such as coffee (Costa et al., 2018; Costa et al., 2019; Costa et al., 2020) and lawns 

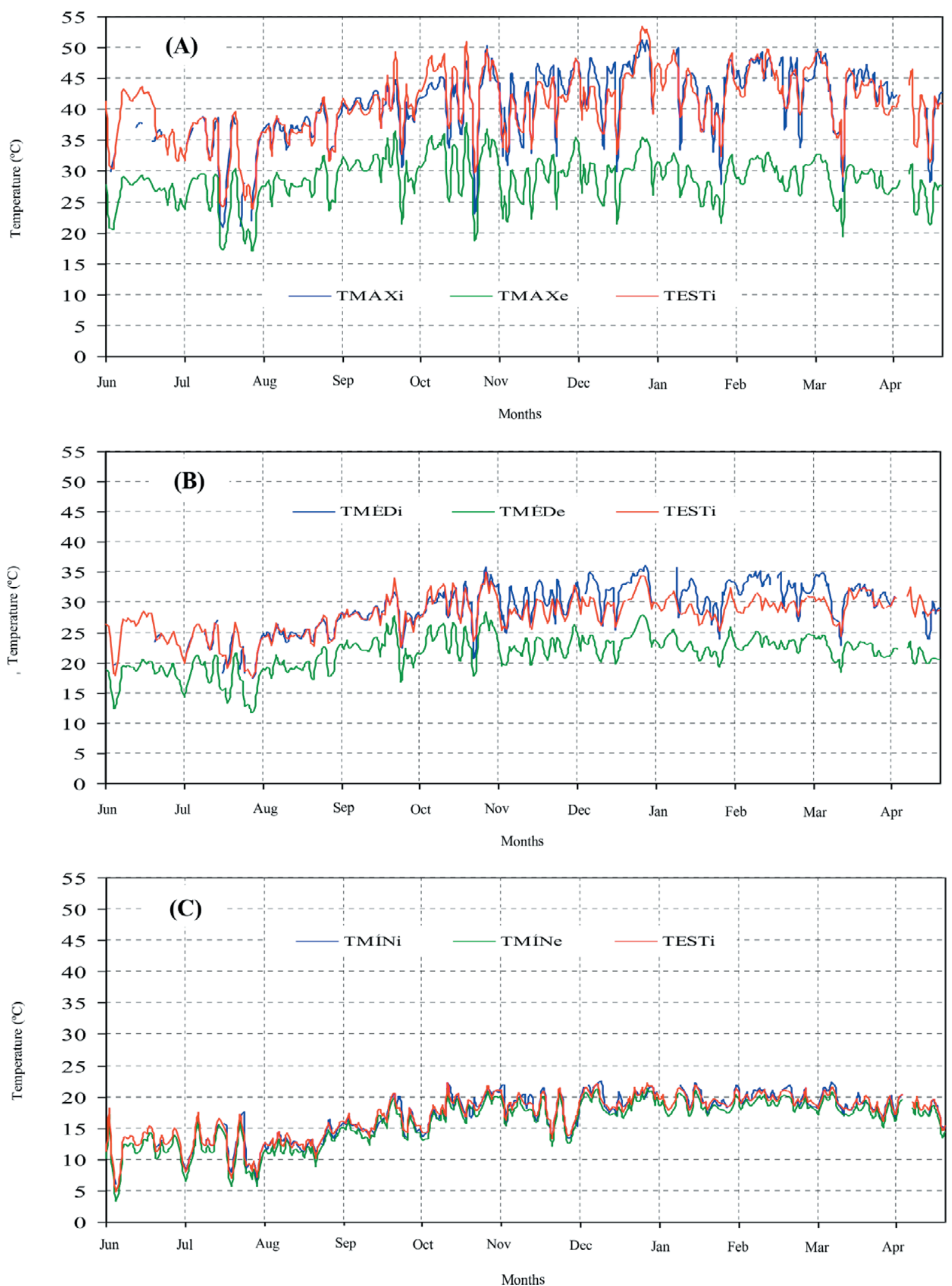

Fig. 2. Maximum (A), average (B) and minimum (C) temperature variation inside the greenhouse, outside and simulated outside during the experimental period. 
Table 2. Average values pepper yield for the populations of 3636 $\left(\mathrm{PROD}_{1}\right)$ and 10000 plants ha ${ }^{-1}\left(\mathrm{PROD}_{2}\right)$.

\begin{tabular}{lcc}
\hline & $\operatorname{PROD}_{1}\left(\mathrm{~kg} \mathrm{ha}^{-1}\right)$ & $\operatorname{PROD}_{2}\left(\mathrm{~kg} \mathrm{ha}^{-1}\right)$ \\
\hline Pepper yield $^{*}$ & 9330.55 & 25272.73 \\
\hline
\end{tabular}

* yield values were obtained per plant and extrapolated to values in $\mathrm{kg} \mathrm{ha}^{-1}$ considering two plant populations.

(Tapparo et al., 2019), showing that the average temperature is the most important variable when compared to the extreme maximum and minimum values.

Fig. 3 shows the comparison between the temperatures obtained inside the greenhouse and outside during the pepper cycle, using RLS. The diagrams A, B, C and $\mathrm{D}$ correspond to the relationship between the $\mathrm{T}_{\mathrm{MAX}}$ in the two environments and, respectively, the seasons of autumn, winter, spring and summer, just as, E, F, G and $\mathrm{H}$ correspond to the $\mathrm{T}_{\mathrm{MED}}$ and $\mathrm{I}, \mathrm{J}, \mathrm{L}$ and $\mathrm{M}$ at $\mathrm{T}_{\mathrm{MIN}}$. Regardless of the determination coefficient $\left(\mathrm{R}^{2}\right)$ values, ranging from 0.65 to 0.95 , all RLS equations were significant at $1 \%$ probability $\left.{ }^{(*}\right)$.

Comparing the obtained values of $\mathrm{T}_{\text {MAX }}$ inside the greenhouse and outside, it was found that the $\mathrm{R}^{2}$ were $73,91,73$ and $84 \%$ for the autumn, winter, spring and summer seasons (Fig. 3A, 3B, 3C and 3D), respectively, and therefore classified as good, excellent, good and very good. The $\mathrm{R}^{2}$ values for $\mathrm{T}_{\mathrm{MED}}$ were $90,93,66$ and $67 \%$, being classified as very good, excellent, and the last two regular for the respective seasons (Fig. 3E, 3F, 3G and $3 \mathrm{H}$ ). For $\mathrm{T}_{\text {MIN }}, \mathrm{R}^{2}$ values were $89,91,87$ and $84 \%$ for the respective seasons (Fig. 3I, 3J, 3L and 3M) and classified as very good, excellent and the last two very good.

Comparisons were also obtained between the temperatures collected inside the greenhouse and outside during the whole pepper cycle, which comprised between 23 DAT, initial phase, and 350 DAT, last harvest, in an interval of 327 days. The RLS equations, significant at $1 \%$ probability, were: $\mathrm{T}_{\text {MAXIN }}=1.315 \mathrm{~T}_{\text {MAXOUT }}$ +3.004 (Equation 6); $\mathrm{T}_{\text {MEDIN }}=1.063 \mathrm{~T}_{\text {MEDOUT }}+4.777$ (Equation 7) and $\mathrm{T}_{\text {MININ }}=0.964 \mathrm{~T}_{\text {MINOUT }}+1.594$ (Equation 8) for $\mathrm{T}_{\mathrm{MAX}}, \mathrm{T}_{\mathrm{MED}}$ and $\mathrm{T}_{\mathrm{MIN}}$, respectively. The values of $\mathrm{R}^{2}$, referring to equations 6,7 and 8 , and their ratings were 0.713 (Good), 0.876 (Very good) and 0.943 (Excellent).

Therefore, given all the RLS equations, it can be said that they generally had a very good correlation. However, in order to have a better accuracy in the estimates of $\mathrm{T}_{\text {MAX }}, \mathrm{T}_{\text {MED }}$ and $\mathrm{T}_{\text {MIN }}$ inside the greenhouse, the equations with the largest $\mathrm{R}^{2}$ for each period should be used. It is advisable to estimate $\mathrm{T}_{\mathrm{MAX}}$ throughout the year, the equations of autumn, winter, spring and summer. For
$\mathrm{T}_{\mathrm{MED}}$, the autumn and winter equations, and Equation 7 in the spring-summer period. In the $\mathrm{T}_{\mathrm{MIN}}$ estimate, only Equation 8.

\subsection{Air relative humidity variation and correlation}

Fig. 4A, 4B and 4C illustrate, respectively, the variations in the maximum $\left(\mathrm{RH}_{\mathrm{MAX}}\right)$, average $\left(\mathrm{RH}_{\mathrm{MED}}\right)$ and minimum $\left(\mathrm{RH}_{\mathrm{MIN}}\right)$ relative humidity (observed and estimated) inside the greenhouse and outside during the pepper cycle, which comprised between 23 DAT, initial phase, and 350 DAT, last harvest, within 327 days.

The average values of $\mathrm{RH}_{\mathrm{MAX}}$ observed inside the greenhouse and outdoors for the autumn, winter, spring and summer seasons were 85 and $100 \%, 81$ and $99 \%, 81$ and $99 \%$ and 85 and $100 \%$, respectively, representing a percentage difference of approximately 15, 18, 18 and $15 \%$. For $\mathrm{RH}_{\mathrm{MED}}$, the mean values were, respectively, 53 and $89 \%, 52$ and $77 \%, 55$ and $81 \%$ and 55 and $90 \%$, with a significant difference of approximately $40,32,32$ and $39 \%$. Finally, $\mathrm{RH}_{\mathrm{MIN}}$, which presented the respective average values of 26 and 59\%, 27 and 44\%, 28 and 52\% and 26 and $62 \%$, representing a significant difference of approximately 56, 39, 46 and 58\%.

Vasquez et al. (2005), working in a greenhouse, in the same place, in the spring-summer season from 2001 to 2002, found values of $\mathrm{RH}_{\mathrm{MAX}}, \mathrm{RH}_{\mathrm{MED}}$ and $\mathrm{RH}_{\mathrm{MIN}}$ of 90, 73 and 50\%, respectively. Frizzone et al. (2005), also in the same place, in the summer of 2001, observed $\mathrm{RH}_{\mathrm{MED}}$ of $76 \%$.

From the beginning to the end of the cultivation cycle, in general, the average values of $\mathrm{RH}_{\mathrm{MAX}}, \mathrm{RH}_{\mathrm{MED}}$ and $\mathrm{RH}_{\mathrm{MIN}}$ observed inside the greenhouse and outside were 87 and $100 \%, 55$ and $92 \%$ and 27 and $67 \%$, respectively, a difference of 13,40 and $60 \%$. It was observed that the $\mathrm{RH}_{\text {MAX }}, \mathrm{RH}_{\mathrm{MED}}$ and $\mathrm{RH}_{\text {MIN }}$ measured in the outdoor environment was always higher than that measured inside the greenhouse and that there was a growing trend in the difference between the humidity obtained inside and outside the greenhouse. This growing trend shows that the greenhouse inside the $\mathrm{RH}_{\mathrm{MAX}}$ approaches the one obtained in the outdoor environment, while the $\mathrm{RH}_{\mathrm{MIN}}$ away.

Normally, relative humidity values approach each other in both environments and are sometimes lower inside the greenhouse (Montero et al., 1984; Farias et al., 1994; Rosenberg et al., 1989). However, such results were expected, since pepper cultivation was carried out in vases, so the area of influence of the wet soil area probably corresponded to a maximum of $36 \%$ of the cultivation spacing area, in the period of greatest water demand of the crop. 

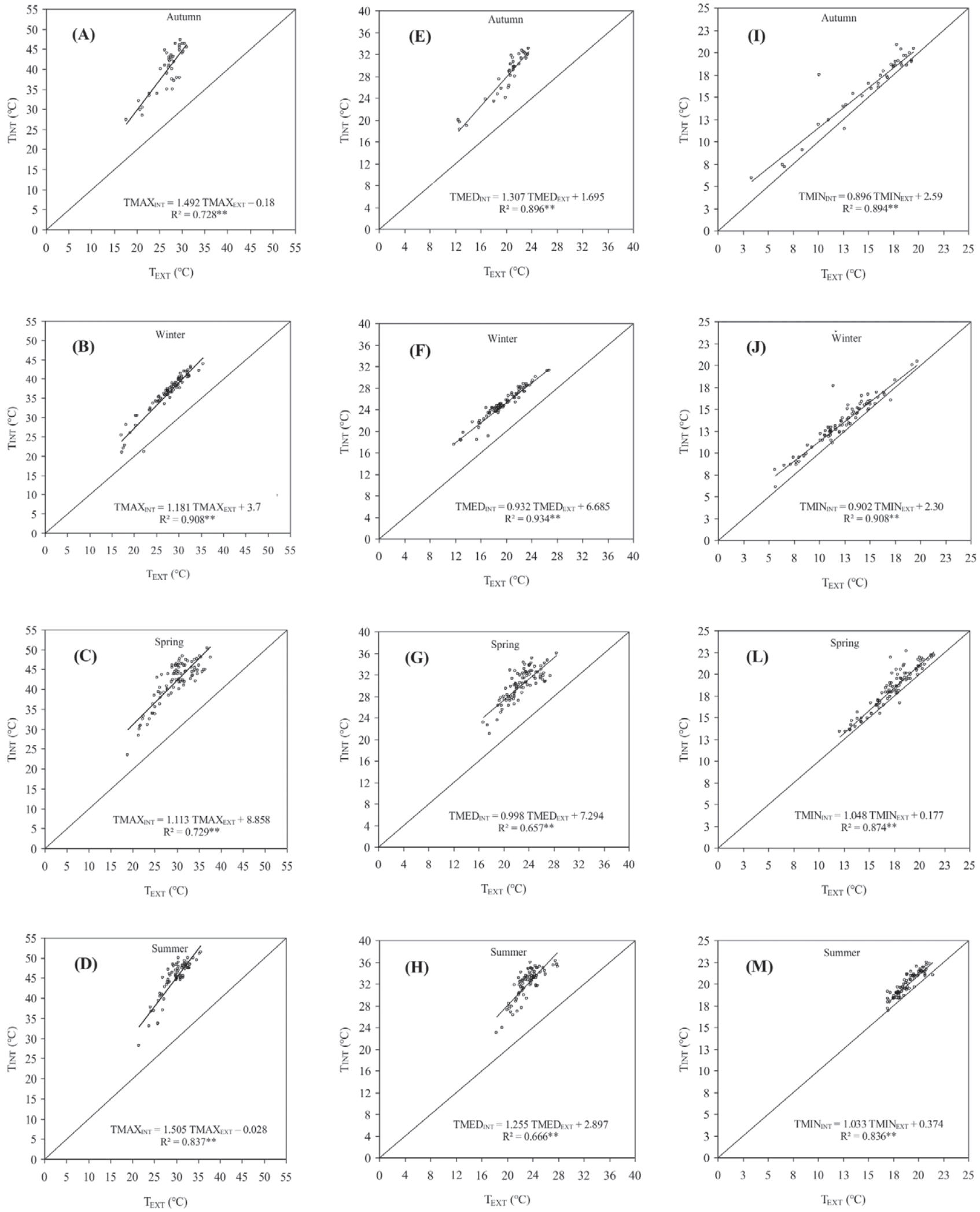

Fig. 3. Relationship between internal and external temperatures for maximum (A, B, C and D), average (E, F, G and H) and minimum (I, J, $\mathrm{L}$ and $\mathrm{M}$ ) values, with the respective seasons of autumn, winter, spring and summer during the experimental period. 

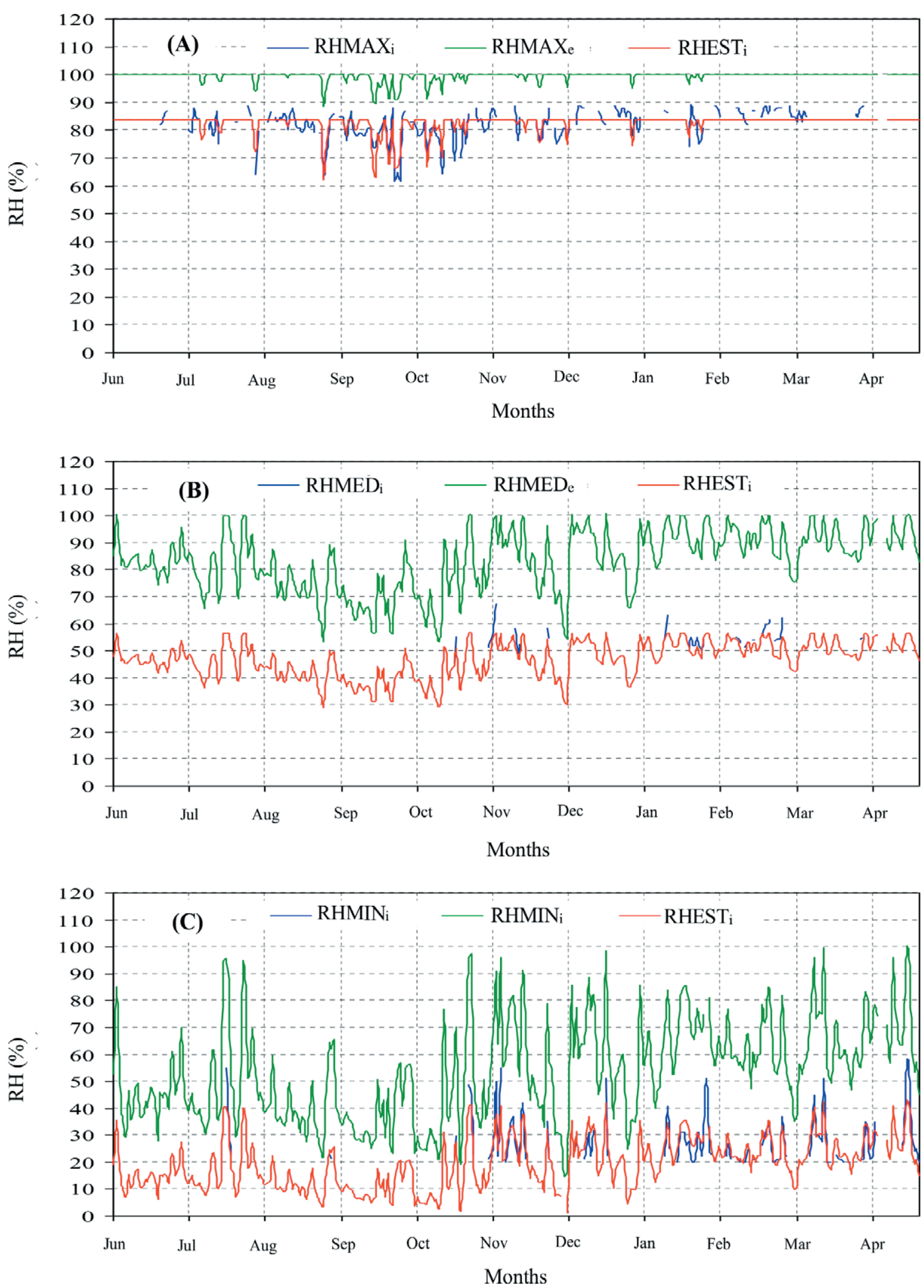

Fig. 4. Maximum (A), average (B) and minimum (C) relative humidity variation, inside the greenhouse, outside and simulated outside during the experimental period. 
In addition, the management of drip irrigation also provides a smaller wet area. Therefore, it can be concluded that the greenhouse, the cultivation in vases and the management of drip irrigation were factors of change in the relative humidity inside the greenhouse. At no time during the pepper crop cycle, the relative humidity was above $95 \%$, probably due to the crop condition.

During the experimental period, there was a failure in the humidity sensors of the station installed inside the greenhouse. When the relative humidity of the air is below $20 \%$ the sensor was unable to quantify and a considerable amount of data was lost.

Fig. 5A, 5B and 5C correspond to the relationship between $\mathrm{RH}_{\mathrm{MAX}}, \mathrm{RH}_{\mathrm{MED}}$ and $\mathrm{RH}_{\mathrm{MIN}}$ in both environments, respectively. Comparing the obtained values of $\mathrm{RH}_{\mathrm{MAX}}, \mathrm{RH}_{\mathrm{MED}}$ and $\mathrm{RH}_{\text {MIN }}$ inside the greenhouse and outside environment, it is verified that the $\mathrm{R}^{2}$ were $53 \%$ (Fig. 5A), 68\% (Fig. 5B) and 69\% (Fig. 5C), respectively, classified as bad and the last two regulars.

Regardless of the values of $\mathrm{R}^{2}$, all RLS equations were significant at $1 \%$ probability $\left.{ }^{* *}\right)$. Therefore, given the RLS equations, it can be said that, in general, they had a regular correlation. However, in order to have a better accuracy of the relative humidity estimates inside the greenhouse, the $\mathrm{RH}_{\mathrm{MED}}$ equation (Fig. 4B) should be used because it has the largest $R^{2}$ and represents the average condition of the environment.

\subsection{Reference Evapotranspiration variation and correlation}

During the conduction period of the pepper was monitored the variation of mini-pan evaporation (EMT), observed (ob) and estimated (e) inside the greenhouse, and the respective $\mathrm{ET}_{0}$, estimated outside Penman-Monteith-PM (Fig. 6A), Hargreaves-Samani (HS) (Fig. 6B) and class "A" pan evaporation (ECA) (Fig. 6C) methods.

An important aspect refers to the EMTob inside the greenhouse (Fig. 6A, 6B and 6C), which covers only the interval from August to December, ie 140 days. The difference between 330 and 140 days is due to the discard of collected data that do not represent the reality of EMTob inside the greenhouse. This occurred from December, because of the shading of the mini-pan by the pepper plants. Also, it can be seen in Fig. 6C that there was a period without data recording, caused by a possible failure of operation of the class " $\mathrm{A}$ " evaporimeter of the weather station.

In April, June, July and August, the EMTe inside the greenhouse was higher than the estimated $\mathrm{ET}_{\mathrm{o}} \mathrm{PM}$ for the external environment, by 11, 2, 15 and 10\%, respectively (Fig. 6A). The total $\mathrm{ET}_{\mathrm{o}} \mathrm{PM}$ values in these respective months were 54, 67, 60 and $90 \mathrm{~mm}$, with means of $2.14,2.25,1.94$ and $2.89 \mathrm{~mm} \mathrm{day}^{-1}$. For the months of September, October, November, December, January, February and March, EMTe corresponded, respectively, to

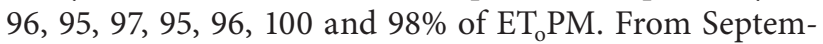
ber to March, the monthly $\mathrm{ET}_{\mathrm{o}} \mathrm{PM}$ values were 111,120 , 106, 125, 96, 108 and $107 \mathrm{~mm}$, respectively, with averages of $3.69,3.88,3.52,4.03,3.10,3.71$ and $3.45 \mathrm{~mm} \mathrm{day}^{-1}$. However, at the end of the pepper growing cycle, it was found that there was no difference between the values obtained from the EMTe inside the greenhouse (1042 $\mathrm{mm}$ ) and the estimated $\mathrm{ET}_{\mathrm{O}} \mathrm{PM}$ in the outside environment (1045 mm).

Similar to the behavior observed in the EMTe in relation to $\mathrm{ET}_{\mathrm{o}} \mathrm{PM}$ (Fig. 6A), in April, June, July and August, the EMTe inside the greenhouse was higher than the estimated $\mathrm{ET}_{\mathrm{o}} \mathrm{ECA}$, for the outside environment, at 7, 16, 17 and 3\%, respectively (Fig. 6C). The total ET ECA values in these respective months were 67, 68, 68 and 91 $\mathrm{mm}$, with averages of 2.69, 2.26, 2.20 and $2.94 \mathrm{~mm} \mathrm{day}^{-1}$.
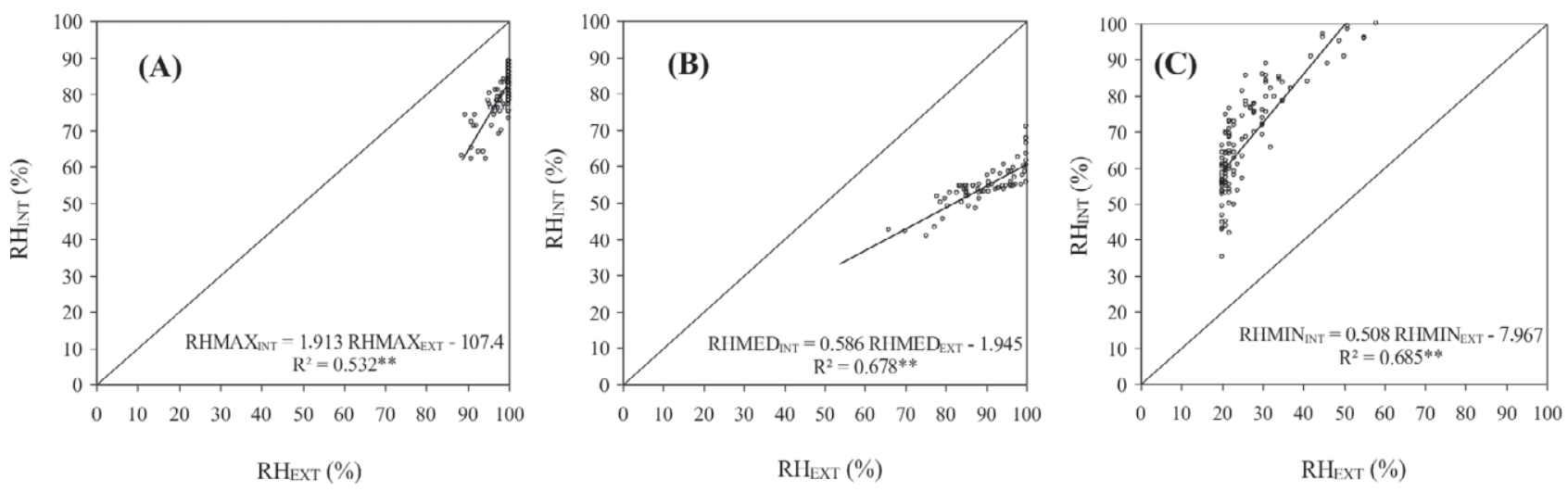

Fig. 5. Relationship between the relative humidity inside the greenhouse and the external environment, for the maximum (A), average (B) and minimum $(\mathrm{C})$ values during the experimental period. 

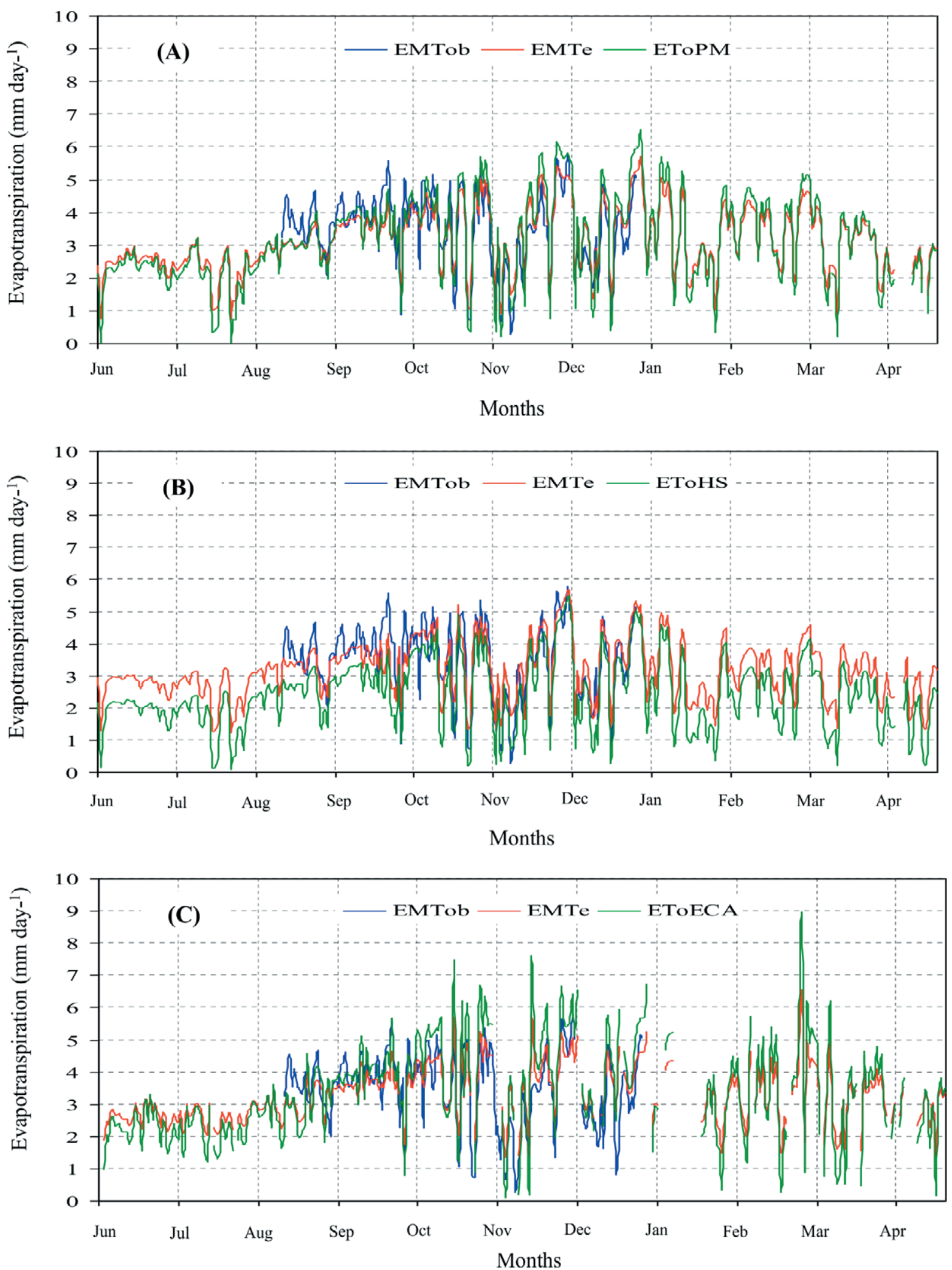

Fig. 6. Observed (ob), estimated (e) and mini-pan evaporation variation inside the greenhouse and respective reference evapotranspirations $\left(\mathrm{ET}_{\mathrm{o}}\right)$ in the outside environment, estimated by Penman-Monteith-PM (A), Hargreaves-Samani-HS (B) and evaporation of the class "A" panECA (C) during the experimental period. 
For the months of September, October, November, December, January, February and March, EMTe corresponded, respectively, to $92,87,92,88,100,94$ and $97 \%$ of $\mathrm{ET}_{\mathrm{o}} \mathrm{ECA}$. From September to March, the monthly $\mathrm{ET}_{\mathrm{o}} \mathrm{ECA}$ values were 117, 140, 117, 138, 97, 107 and 104 $\mathrm{mm}$, respectively, with averages of $3.89,4.52,3.91,4.45$, $3.12,3.70$ and $3.34 \mathrm{~mm} \mathrm{day}^{-1}$. In general, at the end of the pepper crop cycle, the EMTe corresponded to $97 \%$ of $\mathrm{ET}_{0} \mathrm{ECA}$, with respective values of 1080 and $1113 \mathrm{~mm}$.

The EMTe inside the greenhouse was higher than the estimated PM and ECA evapotranspirations for the outside environment in April, June, July and August, and lower in September, October, November, December, January, February and March, respectively, autumnwinter and spring-summer seasons. According to several authors (Montero et al., 1984; Farias et al., 1994; Rosenberg et al., 1989), the partial opacity of the plastic film to solar radiation and the reduction of wind action are the main factors of evaporative demand of the sun, although the higher temperature and lower relative humidity inside the greenhouse compared to the outside environment may at times contribute to higher $\mathrm{ET}_{0}$.

Thus, it can be said that, probably, in the conditions under which the experiment was performed, the effect of plastic film opacity on solar radiation and the reduction of wind action in the autumn-winter season was lower than in the spring-summer season, prevailing the influence of higher temperature and lower humidity on $\mathrm{ET}_{\mathrm{o}}$ inside the greenhouse. In contrast, in the springsummer season, the effect of plastic film opacity on solar radiation and the reduction of wind action was greater than in the autumn-winter season, highlighting the temperature and humidity variables. Even with the greater range of variation of high temperatures and low humidity between the interior of the greenhouse and the outside environment, in the spring-summer season, the $\mathrm{ET}_{\mathrm{o}}$ inside the greenhouse was lower than that observed in the outside environment.

Comparing the results obtained from the EMTe inside the greenhouse with the estimated $\mathrm{ET}_{0} \mathrm{HS}$ for the outside environment (Fig. 6B), it was found that in all months of data collection the EMTe was higher in 43, $56,30,24,20,27,19,36,27,28$ and $51 \%$, respectively, to $\mathrm{ET}_{\mathrm{o}} \mathrm{HS}$. The corresponding monthly $\mathrm{ET}_{\mathrm{o}} \mathrm{HS}$ values were $58,50,77,85,97,79,98,68,76,79$ and $42 \mathrm{~mm}$, with respective averages of $1.92,1.60,2.47,2.83,3.12,2.63$, $3.15,2.19,2.61,2.55$ and $1.69 \mathrm{~mm}^{-1 a y}{ }^{-1}$. At the end of the pepper cultivation cycle, it was observed that the EMTe was $1049 \mathrm{~mm}$ and the $\mathrm{ET}_{\mathrm{o}} \mathrm{HS} 806 \mathrm{~mm}$, representing a difference of $23 \%$.

The HS method was developed for dry climate regions in California's semi-arid conditions (Hargreaves and Samani, 1982). In this context, the HS method may not be good for $\mathrm{ET}_{0}$ estimates in wet climate regions, with a tendency to underestimate the values (Fig. 7).

Fig. 8 shows the comparison between the EMT obtained inside the greenhouse and the $\mathrm{ET}_{\mathrm{o}}$ outside during the pepper cycle by RLS. Diagrams A, B, C and D correspond to the relationship between EMT and $\mathrm{ET}_{\mathrm{o}}$ estimated by PM, for the average intervals of $1,3,5$ and 7 days, respectively, as well as, E, F, G and $\mathrm{H}$ correspond to the EMT and $\mathrm{ET}_{\mathrm{o}}$ estimated by $\mathrm{HS}$ and, I, J, L and $\mathrm{M}$ to the EMT and $\mathrm{ET}_{\mathrm{o}}$ estimated by the ECA. Regardless of the $\mathrm{R}^{2}$ values, ranging from 0.55 to 0.81 , all RLS equations were significant at $1 \%$ probability $\left({ }^{* *}\right)$.

Comparing the values obtained from the EMT inside the greenhouse and from the $\mathrm{ET}_{\mathrm{o}} \mathrm{PM}$ outdoors, the $\mathrm{R}^{2}$ was $72,80,69$ and $65 \%$ for the average intervals of $1,3,5$ and 7 days (Fig. 8A, 8B, 8C and 8D), respectively, and therefore classified as good, the first two, and regular, the last two. The $\mathrm{R}^{2}$ values for the relationship between $\mathrm{EMT}$ and $\mathrm{ET}_{0} \mathrm{HS}$ were 68, 81, 69 and 74\%, being classified as fair, very good, fair and good for the respective average day intervals (Fig. $8 \mathrm{E}, 8 \mathrm{~F}, 8 \mathrm{G}$ and $8 \mathrm{H}$ ).

Regarding the relationship between $\mathrm{EMT}$ and $\mathrm{ET}_{\mathrm{o}} \mathrm{E}$ $\mathrm{CA}$, the $\mathrm{R}^{2}$ values were $58,57,57$ and $55 \%$ for the respective average day intervals (Fig. 8I, 8J, 8L and $8 \mathrm{M}$ ) and all classified as regular. Therefore, given all the RLS equations, it can be said that, in general, they had a regular correlation. However, in order to have better accuracy of the EMT estimates for the average 1, 3, 5 and 7 day inter-

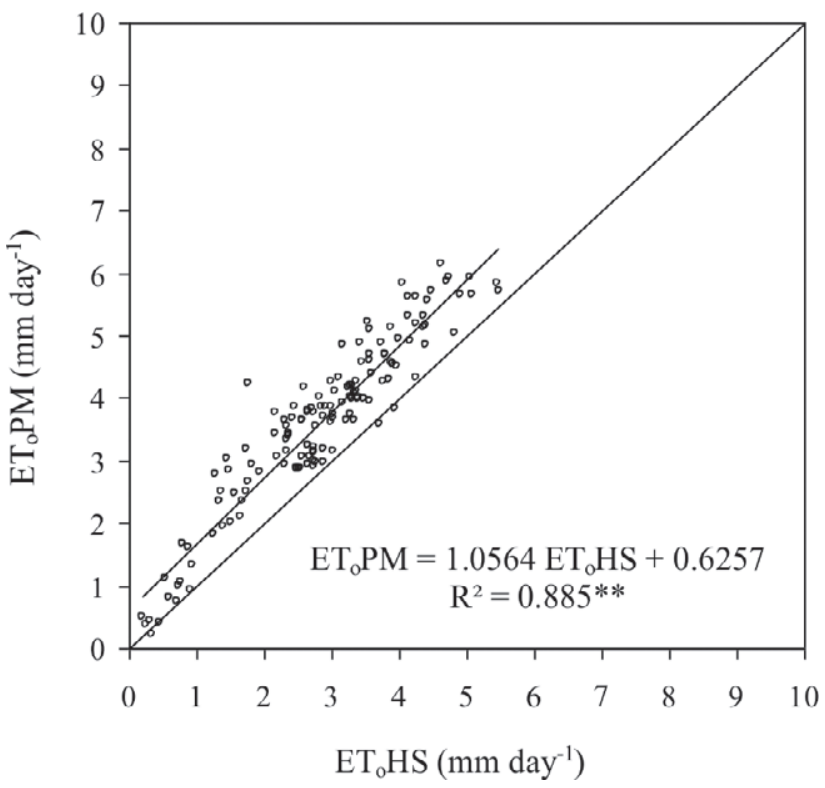

Fig. 7. Relationship between reference evapotranspirations $\left(\mathrm{ET}_{\mathrm{o}}\right)$ in the outside environment, estimated by Penman-Monteith-PM and Hargreaves-Samani-HS, during the experimental period. 

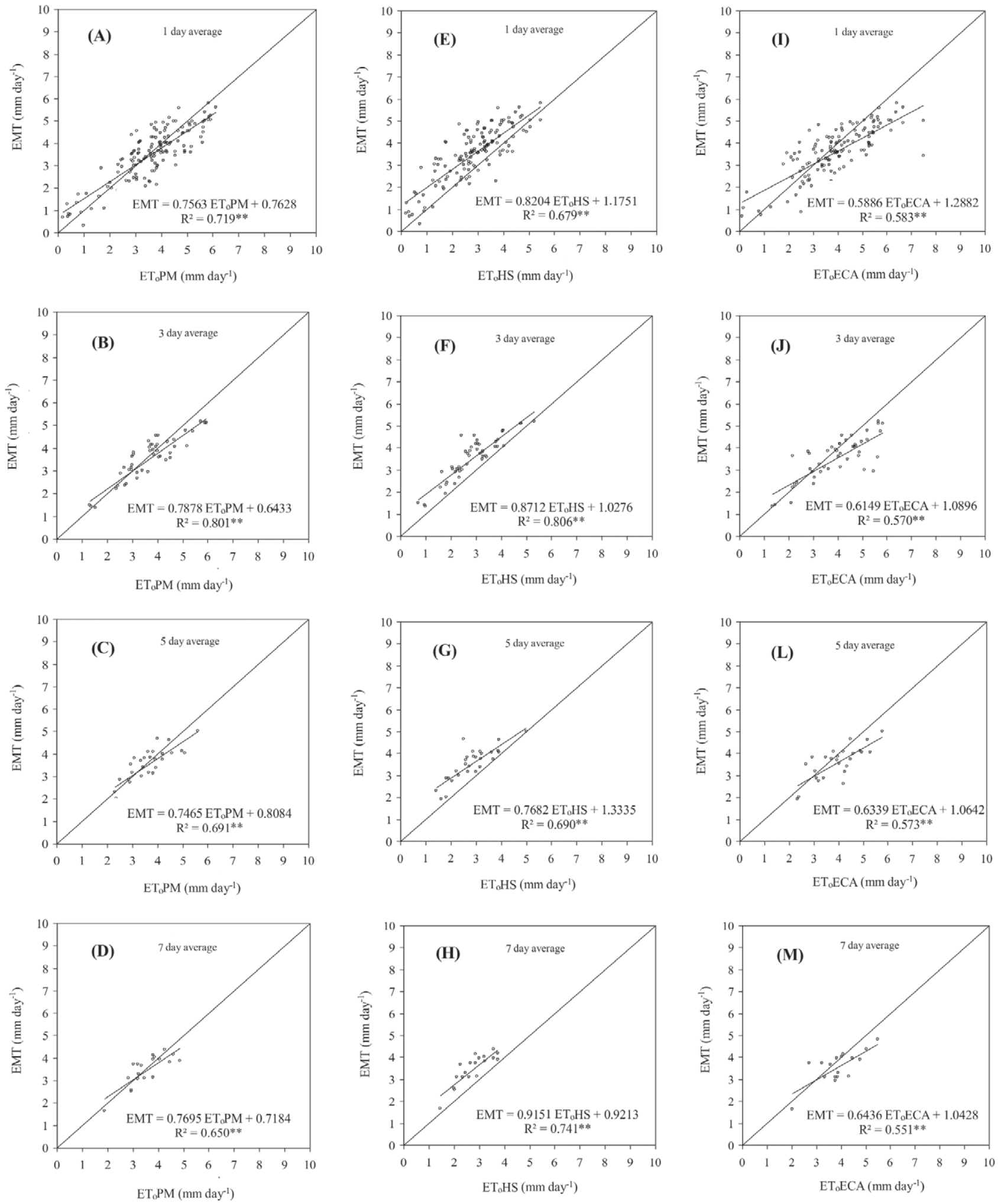

Fig. 8. Relationship between mini-pan evaporation (EMT) inside the greenhouse and reference evapotranspirations $\left(\mathrm{ET}_{\mathrm{o}}\right)$ in the outside environment, estimated by Penman-Monteith-PM (A, B, C and D), Hargreaves-Samani-HS (E, F, G and H) and by evaporation of the class "A" pan-ECA (I, J, L and M), for the averages of 1, 3, 5 and 7 days, respectively, during the experimental period. 
vals within the greenhouse, the equations with the largest $\mathrm{R}^{2}$ should be used for each day interval (due to the irrigation management adopted by the irrigating), combined with the PM method, considered in the literature, the most appropriate for the estimation of $\mathrm{ET}_{\mathrm{o}}$. Therefore, it is advisable to estimate the EMT, for the average intervals of 1, 3, 5 and 7 days, the respective equations: $\mathrm{EMT}=0.7556 \mathrm{ET}_{0} \mathrm{PM}+0.7628 ; \mathrm{EMT}=0.7878 \mathrm{ET}_{0} \mathrm{PM}+$ 0.6433; $\mathrm{EMT}=0.7465 \mathrm{ET}_{\mathrm{o}} \mathrm{PM}+0.8084$ and $\mathrm{EMT}=0.7695$ $\mathrm{ET}_{0} \mathrm{PM}+0.7184$, illustrated in Fig. $8 \mathrm{~A}, 8 \mathrm{~B}, 8 \mathrm{C}$ and $8 \mathrm{D}$.

On the other hand, if it is difficult to estimate the $\mathrm{ET}_{\mathrm{o}}$ in the outside environment, mainly due to unavailability of some meteorological data, necessary in the most complex methods, it is recommended, based on the correlations, to use the mini-pan to obtain the evaporative demand, inside the greenhouse, and thus properly manage irrigation. Angelocci et al. (2002) state that the choice of the $\mathrm{ET}_{\mathrm{o}}$ estimation method requires criteria, which depend on factors such as the availability of meteorological data, the required time scale and the climatic conditions for which the methods were developed. For Farias et al. (1994), the use of the mini-pan inside the greenhouse, which is much smaller than the class "A" evaporimeter, seems more advisable because it occupies a smaller area and contributes less to raise the relative humidity of the environment, besides having lower cost and to be more practical.

\subsection{Evapotranspiration and crop coefficient}

During the conduction period, the $\mathrm{ET}_{\mathrm{c}}$, as shown in Fig. 9, was monitored. The $\mathrm{ET}_{\mathrm{c}}$ values ranged from 0.28 to $2.42 \mathrm{~mm} \mathrm{day}^{-1}$. On average, the maximum $\mathrm{ET}_{\mathrm{c}}$ occurred between 163 and 181 DAT, period comprised by the first flowering peak and fruit development. Miranda et al. (2006) found values that ranged from 1.0 to $5.6 \mathrm{~mm} \mathrm{day}^{-1}$, with maximum $\mathrm{ET}_{\mathrm{c}}$, between 80 and 135 DAT. Chaves et al. (2005), observed that on average, the maximum $\mathrm{ET}_{\mathrm{c}}$ was $8.4 \mathrm{~mm}^{\text {day }}{ }^{-1}$ at $100 \mathrm{DAT}$.

In the harvesting period of the first pepper production cycle, between 181 and $256 \mathrm{DAT}$, the $\mathrm{ET}_{\mathrm{c}}$ decreased considerably, reaching average values of $1.40 \mathrm{~mm}$ day $^{-1}$ (Fig. 9). However, after the end of the first cycle, a second flowering and fruit development peak began, mean $\mathrm{ET}_{\mathrm{c}}$ values increased rapidly from 1.40 to $1.81 \mathrm{~mm}$ day 1, between 256 and $282 \mathrm{DAT}$. The maximum $\mathrm{ET}_{\mathrm{c}}$ at the second peak occurred between 282 and 299 DAT. Subsequently, during the harvest period of the second production cycle, between 299 and 350 DAT, the $\mathrm{ET}_{c}$ decreased again, reaching average values of $1.20 \mathrm{~mm}^{\text {day }}{ }^{-1}$.

In general, it can be seen that both the second flowering and fruit development peak and the harvest period

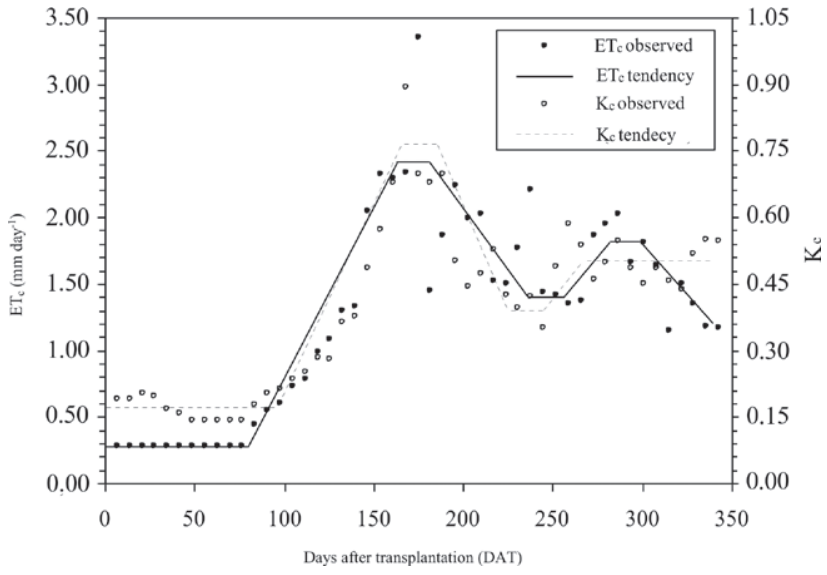

Fig. 9. Variation of crop evapotranspiration $\left(\mathrm{ET}_{\mathrm{c}}\right)$ and crop coefficient $\left(\mathrm{K}_{\mathrm{c}}\right)$ in pepper cultivation in greenhouse, as a function of the phenological phases of the crop and reference evapotranspiration $\left(\mathrm{ET}_{\mathrm{o}}\right)$, estimated for the outside environment by the Penman-Monteith (PM) method.

of the second production cycle did not reach the same $\mathrm{ET}_{c}$ observed in the first production cycle. This behavior was also observed by Miranda et al. (2006). According to the authors, in the climatic conditions of the Northeast region of Brazil, the pepper presents two productive cycles.

The average $\mathrm{ET}_{\mathrm{c}}$ during the conduction period of the pepper crop was $1.28 \mathrm{~mm}^{\text {day }}{ }^{-1}$ in a 350 days cycle. Miranda et al. (2006), obtained an average $\mathrm{ET}_{\mathrm{c}}$ of 2.96 $\mathrm{mm}$ day $^{-1}$ in a cycle of 350 days. While Chaves et al. (2005) found an average $\mathrm{ET}_{\mathrm{c}}$ of $7.40 \mathrm{~mm}$ day $^{-1}$ in 135 days. These differences in $\mathrm{ET}_{\mathrm{c}}$ can probably be attributed to the location of the experiment (Southeast and Northeast Region of Brazil), climatic conditions (mainly solar radiation, temperature, relative humidity and wind speed), the conduction environment of the crop (in greenhouse), planting density (crop spacing), soil type, irrigation management (frequency or watering shift), irrigation system (drip and sprinkler), crop cycle length and the type of lysimeter (drainage and weighing) used to determine the water requirement of the crop.

Fig. 9 shows the variation of $K_{c}$ pepper, by the relationship between $\mathrm{ET}_{\mathrm{c}}$ and $\mathrm{ET}_{\mathrm{o}}$, as a function of the phenological phases of the crop and the $\mathrm{ET}_{\mathrm{o}}$, estimated for the outside environment by the method from PenmanMonteith (PM). Constant values of 0.17 were obtained in the initial phase (0 to 96 DAT), increasing values, on average 0.41 , in the development-flowering phase (96 to 166 DAT), constant values of 0.76 in the flowering-fruiting (166 to $186 \mathrm{DAT})$, decreasing values, averaging 0.49 , in the flowering-fruiting-harvesting phase (186 to 225 DAT), to constant values of 0.39 (225 to 245 DAT). This 
period, between 0 and 245 DAT, was considered the first cycle of pepper production. However, the harvest period lasted until 283 DAT.

For the second pepper production cycle, between 245 and 350 DAT, it was observed that $\mathrm{K}_{\mathrm{c}}$ values were slightly increasing, on average 0.45 , in the final harvest phase of the first production cycle (245 to 283 DAT) and constant, with values of 0.50 in the flowering-fruitingharvest phase (283 to 350 DAT). Miranda et al. (2006) found that the $\mathrm{K}_{\mathrm{c}}$ values for the first cycle of pepper production were 0.30 (21 DAT), 1.22 (90 to $140 \mathrm{DAT}$ ) and 0.65 (165 DAT) for the second cycle yield 0.65 (165 to 180 DAT), 1.08 (200 to $230 \mathrm{DAT}$ ) and 0.60 (225 to 300 DAT). Chaves et al. (2005), observed constant values of 0.96 in the initial phase (0 and 25 DAT), increasing values, on average 1.13, in the development and flowering phase (25 to $75 \mathrm{DAT}$ ), again a trend of constant values of 1.29 in the fruiting phase (75 to 120) and finally decreasing values of 1.24 in the ripening and harvesting phase (120 to 135 DAT).

\section{CONCLUSIONS}

All simple linear regression equations for the air temperature variable generally had a very good correlation. For air humidity and evapotranspiration, in general, the equations presented a regular correlation.

In terms of water demand, the total evaporation value of the mini-pan inside the greenhouse was $1057 \mathrm{~mm}$, in the outside environment, the reference evapotranspirations were 1045, 1113 and $806 \mathrm{~mm}$, respectively, estimated by Penman-Monteith (ET $\mathrm{PM})$, Hargreaves-Samani $\left(\mathrm{ET}_{\mathrm{o}} \mathrm{HS}\right)$ models and class "A" pan evaporation (ECA). In this condition, the evaporation mini-pan (EMT) was virtually equal to $\mathrm{ET}_{0} \mathrm{PM}, 5 \%$ lower than $\mathrm{ET}_{0} \mathrm{HS}$ and $31 \%$ higher than ECA.

During the conduction period of the pepper crop (May 2007 to April 2008), with a 350-day cycle, the evapotranspiration values ranged from 0.28 to 2.42 $\mathrm{mm}$ day $^{-1}$. The total evapotranspiration of the crop was $446.43 \mathrm{~mm}$, with a water consumption of 1227.68 liters per plant.

The crop coefficient $\left(\mathrm{K}_{\mathrm{c}}\right)$ values for the first pepper production cycle were: 0.17 in the initial phase of development (0 to 96 DAT), 0.76 in the flowering and fruiting phase (166 to 186 DAT) and 0.39 . In the harvest phase (225 to $245 \mathrm{DAT}$ ), for the second production cycle, the $\mathrm{K}_{\mathrm{c}}$ value was 0.50 (283 to $350 \mathrm{DAT}$ ).

Future research may consider our study in order to obtain more accurate $\mathrm{K}_{\mathrm{c}}$ for pepper crop in field conditions. These prospects for improvement will depend on the control of climatic factors (mainly rains) in experiments outside the greenhouse and obtaining $\mathrm{ET}_{\mathrm{o}}$ inside the greenhouse following the protocols that are recommended by the FAO bulletin.

\section{ACKNOWLEDGEMENTS}

This study was funded by three sources: a) Coordenação de Aperfeiçoamento de Pessoal de Nível Superior Brasil (CAPES), b) Conselho Nacional de Desenvolvimento Científico e Tecnológico ( $\mathrm{CNPq}$ ) and c) Universidade de São Paulo (USP/ESALQ).

\section{REFERENCES}

Abdel-Ghany, A.M. 2011. Solar energy conversions in the greenhouses. Sustainable Cities and Society 1: 219226. https://doi.org/10.1016/j.scs.2011.08.002.

Allen, R.G., Jensen, M.E., Wright, J.L., Burman, R.D. 1989. Operational estimates of reference evapotranspiration. Agronomy journal 81: 650-662. https://doi. org/10.2134/agronj1989.00021962008100040019x.

Allen, R.G., Pereira, L.S., Raes, D., Smith, M. 1998. Crop evapotranspiration-Guidelines for computing crop water requirements-FAO Irrigation and drainage paper 56. FAO, Rome, 300: D05109.

Alvares, C.A., Stape, J.L., Sentelhas, P.C., Gonçalves, J.L.M., Sparovek, G. 2013. Köppen's climate classification map for Brazil. Meteorologische Zeitschrift 22: 711-728. http://dx.doi.org/10.1127/09412948/2013/0507.

Andrade Júnior, A.S.D., Damasceno, L.M., Dias, N.D.S., Gheyi, H.R., Guiselini, C. 2011. Climate variations in greenhouse cultivated with gerbera and relationship with external conditions. Engenharia Agrícola 31: 857-867. http://dx.doi.org/10.1590/S010069162011000500003.

Chavarria, G., Herter, F.G., Raseira, M.D.C.B., Rodrigues, A.C., Reisser, C., Silva, J.B.D. 2009. Mild temperatures on bud breaking dormancy in peaches. Ciência Rural 39: 2016-2021. http://dx.doi.org/10.1590/ S0103-84782009000700010.

Chaves, S.W.P., Azevedo, B.M.de, Medeiros, J.F.D., Bezerra, F.M.L., Morais, N.B.de. 2005. Evapotranspiração e coeficiente de cultivo da pimenteira em lisímetro de drenagem. Revista Ciência Agronômica 36: 262-267.

Costa, J.de.O., Almeida, A.N.de, Coelho, R.D., Folegatti, M.V., José, J.V. 2015. Modelos de estimativa de elementos micrometeorológicos em ambiente protegido. Water Resources and Irrigation Management 
4, 25-31. http://dx.doi.org/10.19149/2316-6886/wrim. v4n1-3p25-31.

Costa, J.de.O., Coelho, R.D., Barros, T.H.da.S., Fraga Junior, E.F., Fernandes, A.L.T. 2018. Physiological responses of coffee tree under different irrigation levels. Engenharia Agrícola, 38, 648-656. http://dx.doi.org/10.1590/1809-4430-eng.agric. v38n5p648-656/2018.

Costa, J.de.O., Coelho, R.D., Barros, T.H.da.S., Fraga Junior, E.F., Fernandes, A.L.T. 2019. Leaf area index and radiation extinction coefficient of a coffee canopy under variable drip irrigation levels. Acta Scientiarum. Agronomy, 41, 1-8. http://dx.doi.org/10.4025/ actasciagron.v41i1.42703.

Costa, J.de.O., Coelho, R.D., Barros, T.H.da.S., Fraga Junior, E.F., Fernandes, A.L.T. 2020. Canopy thermal response to water deficit of coffee plants under drip irrigation. Irrigation and Drainage 69, 472-482. https://doi.org/10.1002/ird.2429.

Doorenbos, J.; Kassam, A.H. 2000. Efeito da água no rendimento das culturas. 2. ed. Trad. de H.R. Gheyi et al. Campina Grande: UFPB, 2000. 221p.

Farias, J.R.B., Bergamaschi, H., Martins, S.R. 1994. Evapotranspiração no interior de estufas plásticas. Revista Brasileira de Agrometeorologia 2: 17-22.

Frizzone, J.A., Cardoso, S.da.S., Rezende, R. 2005. Produtividade e qualidade de frutos de meloeiro cultivado em ambiente protegido com aplicação de dióxido de carbono e de potássio via água de irrigação. Acta Scientiarum. Agronomy 27: 707-717.

Giménez, C., Gallardo, M., Martínez-Gaitán, C., Stöckle, C.O., Thompson, R.B., Granados, M.R. 2013. VegSyst, a simulation model of daily crop growth, nitrogen uptake and evapotranspiration for pepper crops for use in an on-farm decision support system. Irrigation Science 31: 465-477. https://doi.org/10.1007/s00271-011-0312-2.

Hargreaves, G.H., Samani, Z.A. 1982. Estimating potential evapotranspiration. Journal of the irrigation and Drainage Division 108: 225-230.

Kittas, C., Bartzanas, T. 2007. Greenhouse microclimate and dehumidification effectiveness under different ventilator configurations. Building and Environment 42: 3774-3784. https://doi.org/10.1016/j.buildenv.2006.06.020.

Meiri, A., Naftaliev, B., Shmuel, D., Yechezkel, H., Communar, G., Friedman, S.P. 2011. Short-term wateringdistance and symmetry effects on root and shoot growth of bell pepper plantlets. Agricultural water management 98: 1557-1568. https://doi.org/10.1016/j. agwat.2011.05.010.

Mercado, J.A., Mar Trigo, M., Reid, M.S., Valpuesta, V., Quesada, M.A. 1997. Effects of low temperature on pepper pollen morphology and fertility: evidence of cold induced exine alterations. Journal of Horticultural Science 72: 317-326. https://doi.org/10.1080/146 20316.1997.11515518.

Miranda, F.D., Gondim, R.S., Costa, C.A.G. 2006. Evapotranspiration and crop coefficients for tabasco pepper (Capsicum frutescens L.). Agricultural Water Management 82: 237-246. https://doi.org/10.1016/j. agwat.2005.07.024.

Montero, J.I., Castilla, N., Ravé, E.G.de, Bretones, F. 1984. Climate under plastic in the almeria area. Greenhouse Construction and Covering Materials 170: 227-234. https://doi.org/10.17660/ActaHortic.1985.170.26.

Orgaz, F., Fernández, M.D., Bonachela, S., Gallardo, M., Fereres, E. 2005. Evapotranspiration of horticultural crops in an unheated plastic greenhouse. Agricultural water management 72: 81-96. https://doi. org/10.1016/j.agwat.2004.09.010.

Qiu, R., Du, T., Kang, S., Chen, R., Wu, L. 2015. Assessing the SIMDualKc model for estimating evapotranspiration of hot pepper grown in a solar greenhouse in Northwest China. Agricultural Systems 138: 1-9. https://doi.org/10.1016/j.agsy.2015.05.001.

Qiu, R., Kang, S., Li, F., Du, T., Tong, L., Wang, F., Li, S. 2011. Energy partitioning and evapotranspiration of hot pepper grown in greenhouse with furrow and drip irrigation methods. Scientia Horticulturae 129: 790-797. https://doi.org/10.1016/j.scienta.2011.06.012.

Raij, B. van. 1996. Recomendações de adubação e calagem para o Estado de São Paulo. Campinas: IAC.

Rosenberg, N.J., McKenney, M.S., Martin, P. 1989. Evapotranspiration in a greenhouse-warmed world: a review and a simulation. Agricultural and Forest Meteorology 47: 303-320. https://doi. org/10.1016/0168-1923(89)90102-0.

Tapparo, S.A., Coelho, R.D., Costa, J.de.O., Chaves, S.W.P. 2019. Growth and establishment of irrigated lawns under fixed management conditions. Scientia Horticulturae, 256, 108580. https://doi.org/10.1016/j.scienta.2019.108580.

Vásquez, M.A., Folegatti, M.V., Dias, N.D.S., Silva, C.R.da. 2005. Efeito do ambiente protegido cultivado com melão sobre os elementos meteorológicos e sua relação com as condições externas. Engenharia Agrícola 25: 137-143. http://dx.doi.org/10.1590/S010069162005000100015 . 